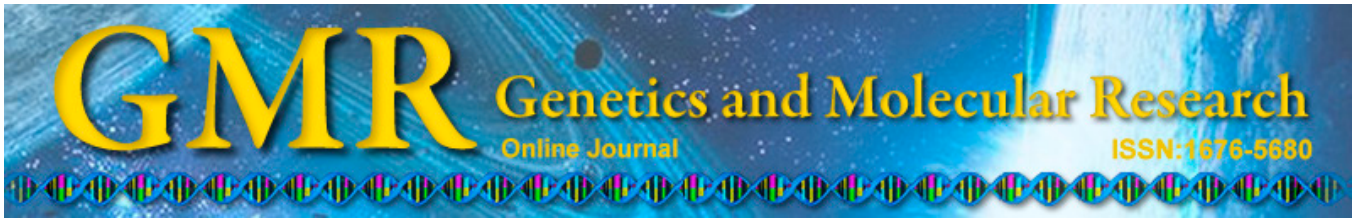

\title{
Identification of differentially expressed genes in a pistillody common wheat mutant using an annealing control primer system
}

\author{
M.L. Liao ${ }^{1}$, Z.S. Peng ${ }^{1}$, Z.J. Yang ${ }^{1}$, S.H. Wei ${ }^{1}$ and P. Martinek ${ }^{2}$ \\ ${ }^{1}$ Key Laboratory of Southwest China Wildlife Resources Conservation, \\ College of Life Science, China West Normal University, Nanchong City, \\ Sichuan, China \\ ${ }^{2}$ Agrotest Fyto, Ltd., Kroměříž, Czech Republic \\ Corresponding author: M.L. Liao \\ E-mail: liao115723@163.com
}

Genet. Mol. Res. 14 (2): 3995-4004 (2015)

Received June 9, 2014

Accepted October 17, 2014

Published April 27, 2015

DOI http://dx.doi.org/10.4238/2015.April.27.14

\begin{abstract}
HTS-1 is a new kind of pistillody wheat. All or parts of its stamen are transformed into pistils or pistil-like structures, and it has more seed sets per floret than normal wheat under normal cultivation conditions. To investigate the expression divergence in this mutant, an annealing control primer system was used to identify differentially expressed genes (DEGs) in the young spikelets. As a result, three DEGs, including $H D B 2, H G F 2$, and $H C G 4$, were detected, with variable expression in HTS-1 and the control. After further confirmation using real-time reverse transcription polymerase chain reaction analysis, these genes were overexpressed in HTS-1 wheat. $N G F 2$ was identified in the double ridge to floret differentiation stages; $H D B 2$ and $H C G 4$ were identified in the stage of pistil and stamen-differentiating. Therefore, we inferred that the homeotic transformation of stamens into pistil-like structures occurred during the early stage of stamen development. Sequence alignment analysis revealed that $H D B 2$ encodes a putative protein of 189 amino acids,
\end{abstract}


with high homology to the DEAD-box ATP-dependent RNA helicase, and $H C G 4$ was identical to the Chinese spring wheat cDNA clone predicted protein according to GenBank. However, NGF2 was not found to have significant similarity to any reported proteins, suggesting it is a new functional gene in wheat. The results suggest that $H D B 2$, $H C G 4$, and $H G F 2$ are minor genes contributing to pistillody trait formation in HTS-1.

Key words: Wheat; Pistillody; Annealing control primer system; Gene function

\section{INTRODUCTION}

The inflorescence of the wheat plant, named the head or spike, is composed of many spikelets that form two opposing rows along the main axis (Shitsukawa et al., 2009). Each spikelet consists of several florets alternately joined at the axis on opposing sides. Commonly, the wheat floret contains one pistil, three stamens, and two lodicules (Leighty and Sando, 1924). The pistil has a central carpel, which is composed of a single ovary with a single ovule (Murai et al., 2002); therefore, only one seed set develops per floret after pollination (Schmidt and Ambrose, 1998).

The three-pistil (TP) mutant, which produces three pistils per floret, was screened by Peng (2003) and proven to be controlled by a single dominant gene, Pis 1, located on chromosome 2D (Peng et al., 2004, 2008; Tiwari et al., 2011). Then, the HTS-1 plant was screened from the near-isogenic lines of TP wheat (CSTP) by Peng et al. (2013). One to three stamens in HTS-1 will also turn into pistils or pistil-like structures (Figure 1), and there are different degrees of transformed stamens in the floret (Figure 2), as has been previously reported in various pistillody plants (Leighty and Sando, 1924; Hanson, 1991; Li et al., 2007). Pistillody is one of the approaches to plant directed evolution from monoclinous to diclinous flowers (Mitchell and Diggle, 2005). Because pistillody phenomena can be seen with the naked eye and they play an important role in evolutionary biology and plant breeding practices, pistillody has received more attention in recent years. In particular, the pistillody-forming molecular mechanism, which is an important aspect of regulation of expression in flower organs, is the most studied phenomenon in relation to plants to date (Meguro et al., 2003; Hama et al., 2004; Saraike et al., 2007; Mizumoto et al., 2009). The alloplasmic line of N26 (Murai and Tsunewaki, 1993) and (cr)-CSdt7BS (Murai et al., 2002) were used as research materials to analyze the genetic and molecular mechanisms of wheat pistillody (Meguro et al., 2003; Saraike et al., 2007; Zhu et al., 2008; Mizumoto et al., 2009). The pistillody phenomena of N26 and (cr)-CSdt7BS are caused by unclear cytoplasmic interactions (Murai et al., 2002; Zhu et al., 2008). However, the pistillody trait of HTS-1 was determined by the interaction of two recessive karyogenes, hts1 and hts2 (Peng et al., 2013). In other words, HTS-1 is different from the previously reported lines (cr)-CSdt7BS and N26. Thus, HTS-1 is a new kind of pistillody wheat.

To study the HTS-1 floral development and identify the molecular mechanism controlling for pistillody characteristics, annealing control primer system (ACP) technology was used to identify the pistillody genes of HTS-1 in this paper. 

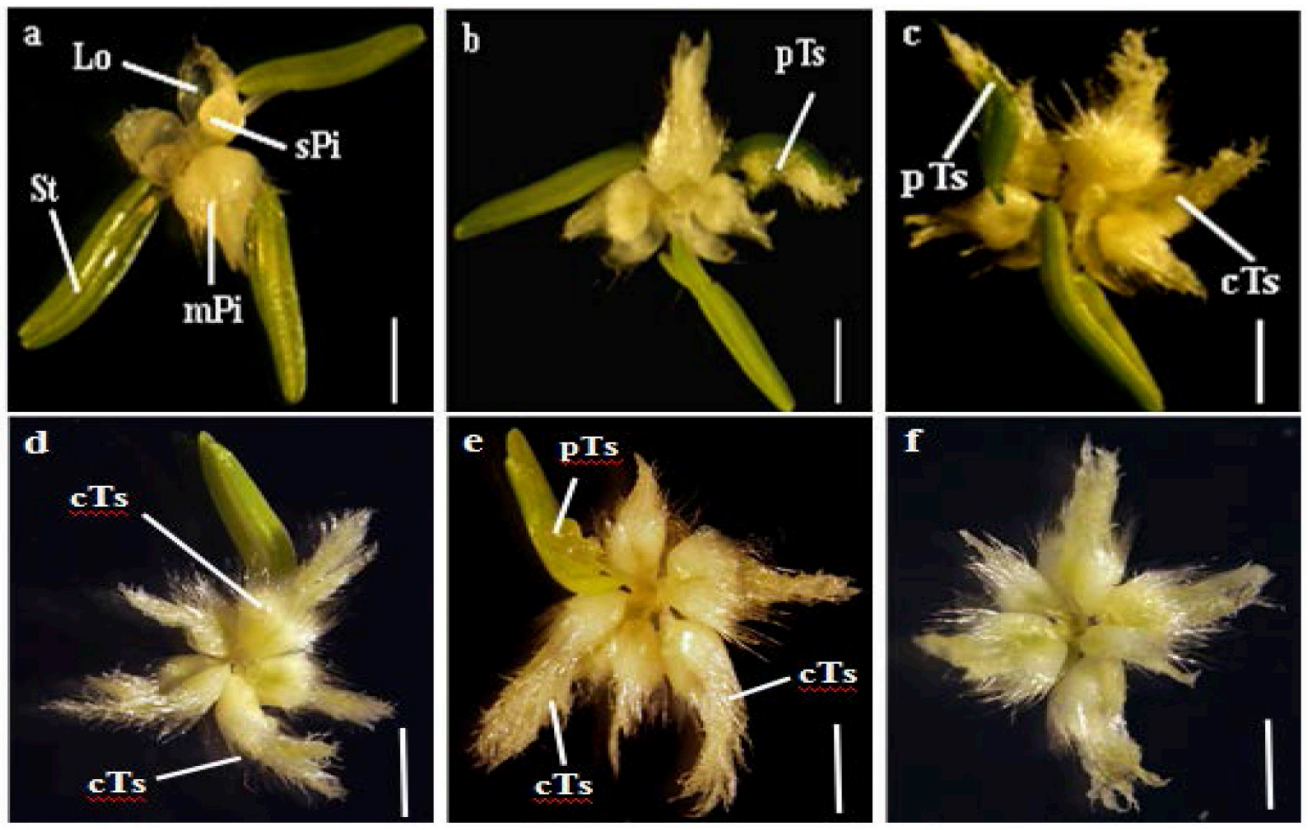

Figure 1. Morphology of the florets in HTS-1 and its sib-line CSTP plant. (a) A floret of the CSTP plant; (b) one stamen transformed into a pistil-like structure in the HTS-1 plant; (c)-(d) two stamens transformed into pistil-like structures in the HTS-1 plant; and (e)-(f) three stamens transformed into pistil-like structures in the HTS-1 plant. St: stamen; mPi: main pistil; sPi: subsidiary; Lo: lodicule; pTs: partially transformed stamen; cTs: completely transformed stamen; Scale bar $=1 \mathrm{~mm}$.

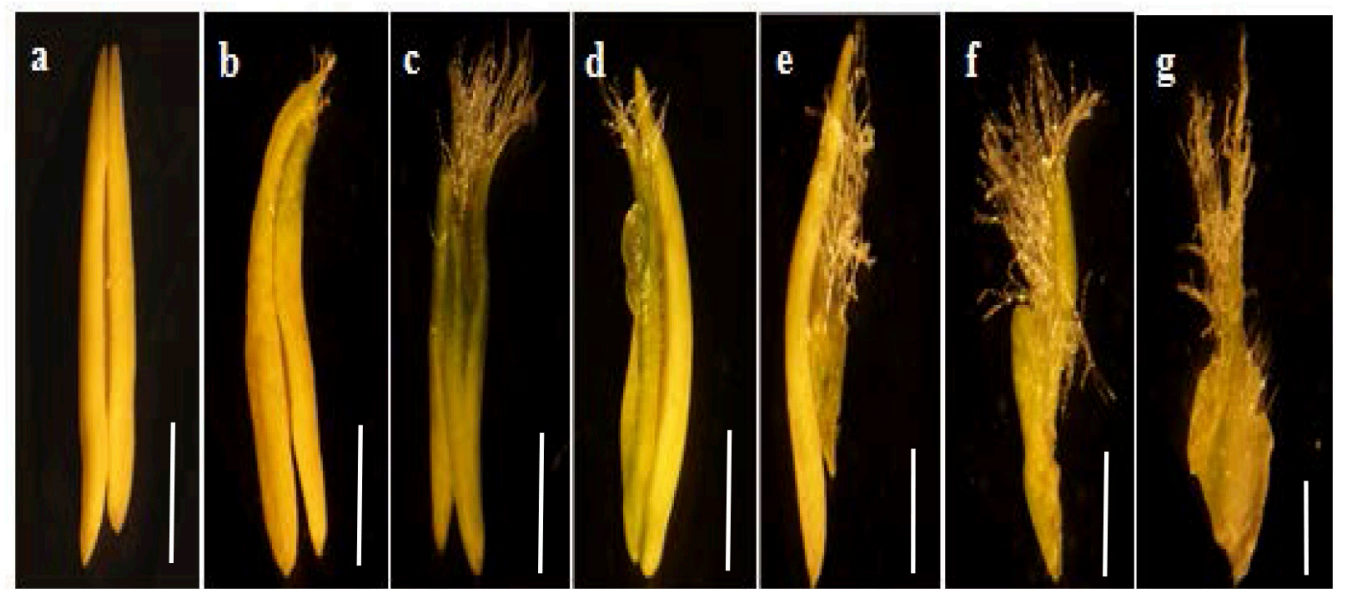

Figure 2. Normal and transformed stamens in HTS-1 wheat. (a) Normal stamen; (b)-(c) slightly transformed stamen; (d)-(f) stamen with high degree of transformation; (g) stamen with complete transformation of the carpel $(1 \mathrm{~mm})$. 


\section{MATERIAL AND METHODS}

\section{Plant material}

The HTS-1 plant, which was screened from the near-isogenic lines of CSTP by Peng et al. (2013), was used in this study. Pistillody wheat HTS-1 and control CSTP were grown in an experimental field at the China West Normal University, Nanchong, China. The homeotic transformation of stamens into pistil-like structures occurred during the early stage of stamen development (Peng et al., 2013). Young spikes were collected during the reproductive stage and examined under a stereomicroscope (Olympus SZX9). The spikes of HTS-1 and CSTP at various developmental stages, including the double ridge to floret differentiation stages (spike size, 2-5 $\mathrm{mm}$ in length), pistil and stamen-differentiating stage (spike size, 5-7 $\mathrm{mm}$ in length), and anther lobe formation stage (spike size, 7-10 mm in length), were selected for real-time polymerase chain reaction (PCR) analysis; briefly frozen in liquid nitrogen; and kept at $-70^{\circ} \mathrm{C}$ until use.

\section{Total RNA isolation}

Total RNA was isolated from young spikelets according to the method of Manickavelu et al. (2007). Generally, DNAse treatment was performed before proceeding with complementary DNA (cDNA) synthesis. The quality of the RNA was confirmed by gel electrophoresis. The concentration was calculated after measurement by a $260 / 280 \mathrm{~nm}$ spectrophotometer.

\section{Isolation and sequencing of differentially expressed genes using ACP}

First-strand cDNA synthesis was performed for $1.5 \mathrm{~h}$ at $42^{\circ} \mathrm{C}$ in a final reaction volume of $20 \mu \mathrm{L}$ containing $500 \mathrm{ng}$ purified total RNA, $4 \mu \mathrm{L}$ reaction buffer, $2 \mu \mathrm{L}$ dNTPs (each $2.5 \mathrm{mM}$; TOYOBO, Shanghai, China), $2 \mu \mathrm{L} 10 \mu \mathrm{M}$ cDNA synthesis primer dT-ACP1, 0.5 $\mu \mathrm{L}$ Super-RI (TOYOBO), $0.5 \mu \mathrm{L}$ RT-Enhancer (TOYOBO), and $1 \mu \mathrm{L}$ ReverTra Ace (100 U/ $\mu \mathrm{L}$; TOYOBO). The synthesized first-strand cDNA samples were diluted by the addition of $10 \mu \mathrm{L}$ ultrapurified water. PCR amplification was conducted using the GeneFishing ${ }^{\mathrm{TM}}$ DEG Kit (Seegene, Seoul, South Korea) in a $50 \mu \mathrm{L}$ reaction volume, which was composed of 5 $\mu \mathrm{L} 10 \mathrm{X}$ buffer without $\mathrm{MgCl}_{2}, 25 \mathrm{mM} \mathrm{MgCl}, 5 \mu \mathrm{m}$ arbitrary ACPs, $10 \mu \mathrm{m}$ dT-ACP2, $2 \mathrm{mM}$ dNTP, $2.5 \mathrm{U}$ Taq DNA polymerase (Applied Biosystems), and $5 \mu \mathrm{L}$ first-strand cDNA. PCR amplification was conducted for one cycle at $94^{\circ} \mathrm{C}$ for $3 \mathrm{~min}, 50^{\circ} \mathrm{C}$ for $3 \mathrm{~min}$, and $72^{\circ} \mathrm{C}$ for $90 \mathrm{~s}$, followed by 40 cycles each at $94^{\circ} \mathrm{C}$ for $15 \mathrm{~s}, 65^{\circ} \mathrm{C}$ for $30 \mathrm{~s}, 72^{\circ} \mathrm{C}$ for $90 \mathrm{~s}$, and $72^{\circ} \mathrm{C}$ for $10 \mathrm{~min}$. The amplified PCR products were separated in $8.0 \%$ polyacrylamide gel and the gels were stained The ACP-based reverse transcription PCR (RT-PCR) was repeated three times. Bands corresponding to potential differentially expressed genes (DEGs) were identified and excised from the polyacrylamide gels with a clean scalpel and purified using the Ezgene ${ }^{\mathrm{TM}}$ Poly-Gel DNA Purification Kit. Subsequently, the purified PCR products were separated on a $2.0 \%$ agarose gel stained with ethidium bromide, excised from the gels using a clean scalpel, and purified using the QIAquick Gel Extraction Kit (Qiagen, Shanghai, China). The amplified potential DEG inserts were subsequently cloned into the pMD19-T vector (TAKARA) according to manufacturer instructions and then transformed into Escherichia coli DH-5a cells. Transformants were plated on LB agar containing ampicillin. Clones with inserts were identified using blue/white colony selection. Positive clones were then screened and sequenced by 
Taihe Biotechnology Co. Ltd. (Beijing, China). Sequences were compared to the database in GenBank using the Blastx program (http://www.ncbi.nlm.nih.gov/).

\section{Quantitative real-time RT-PCR}

For quantitative real-time RT-PCR, the reference genes 18S (GenBank No. AY049040) and actin (GenBank No. AB181911) (Yamada et al., 2009; Wang et al., 2010) were used (Table 1); the PrimeScript Perfect Real-Time RT Reagent Kit (TaKaRa, China) was used for the reactions. The primers were designed using the Primer Express 3.0 software for the HGF2, HDB2, and $H C G 4$ genes (Table 1). PCR was conducted in triplicate and normalized to $18 \mathrm{~S}$ and actin. Real-time expression assays were performed with SYBR Green dye (TaKaRa) using the BIO-RAD CFX-96 real-time PCR platform (Bio-Rad). Fold-changes of RNA transcripts were calculated via the $2^{-\Delta \Delta C t}$ method (Livak and Schmittgen, 2001).

\begin{tabular}{|c|c|c|c|}
\hline Growth stage & Primer & Primer sequence $\left(5^{\prime} \rightarrow 3^{\prime}\right)$ & Amplified products (bp) \\
\hline \multirow[t]{2}{*}{ Double ridge stage to floret differentiation stage } & $H D B 2$ & F: AGGTTGAGAATGTGCTGACACG & 152 \\
\hline & HDB2 & R: GAGTCGGTAGTCTGTTTCTTCAGG & \\
\hline \multirow{2}{*}{ Pistil and stamen-differentiating stage } & $N G F 2$ & F: CTCGCCTCCCAATTTTGACTC & 146 \\
\hline & $N G F 2$ & R: GGACCGTAGCCAATCCATTTC & \\
\hline \multirow[t]{2}{*}{ Anther lobe formation stage } & HCG4 & F: GAGAACGGCAAGAAGGAAGAAG & 123 \\
\hline & HCG4 & R: CCCCAGCAACAAACAAGAACAC & \\
\hline \multirow[t]{4}{*}{ Reference gene } & Actin & F: ACG CTT CCT CAT GCT ATC CTT C & 121 \\
\hline & Actin & R: ATG TCT CTG ACA ATT TCC CGC T & \\
\hline & $18 \mathrm{~S}$ & F: AAGGCGAAGATCCAG GACAAG & 107 \\
\hline & $18 \mathrm{~S}$ & R: TGGATGTTG TAG TCC GCC AAG & \\
\hline
\end{tabular}

\section{Data analysis}

The sequence data were analyzed with the GenScan software (http://genes.mit.edu/ GENSCAN.html). For homology analysis, wheat $H D B 2, N G F 2$, and $H C G 4$ were compared to the amino acid sequences of other species using BLAST 2.1 (http://www.ncbi.nlm.nih.gov/ blast/). The open reading frame (ORF) of the protein sequence was searched using the ORF finder software (http://www.ncbi.nlm.nih.gov/gorf/gorf.html). Basic parameters and secondary structures of the three gene sequences were deduced using the PredictProtein software (https://www.predictprotein.org/). Multiple sequence alignment was performed using the DNAstar Lasergene and the DNAMAN 6.0 software.

\section{RESULTS}

\section{Identification of DEGs between HTS-1 and CSTP}

In order to screen DEGs in HTS-1 plants, the mRNA profiles of HTS- 1 and its sib-line CSTP were assessed at three stages, that is, the double ridge to floret differentiation stages, pistil and stamen-differentiating stage, and anther lobe formation stage and compared by annealing control primer (ACP) RT-PCR using a combination of 120 arbitrary primers and two oligo (dT) primers. From the 120 arbitrary primers tested, three showed differentially expressed 
bands (named $H D B 2, N G F 2$, and $H C G 4$; Figure 3). All of these showed higher expression in HTS-1. NGF2 was identified in the double ridge to floret differentiation stages; HDB2 and $H C G 4$ were identified in the pistil during the stamen-differentiation stage. The three DEGs were successfully excised, purified, and cloned for subsequent sequencing.

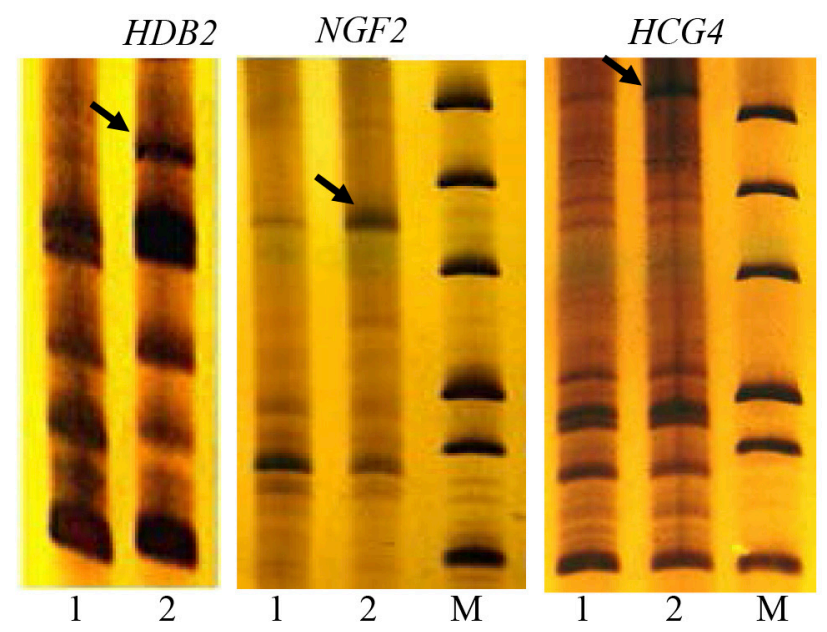

Figure 3. Differential bands on polyacrylamide gel. Lane $M=2000$ bp-DNA marker; lane $1=\mathrm{CSTP}$; lane $2=$ HTS-1.

\section{Confirmation of differential expression}

Real-time PCR was used to confirm the differential expression of three genes (i.e., $H D B 2, N G F 2$, and $H C G 4$ ) in HTS-1 and CSTP plants. The real time-PCR results showed that the differential expression of the three genes (i.e., $H D B 2, N G F 2$, and $H C G 4$ ) were significant. As can be seen in Figure 4, the expression of the three genes in HTS-1 was almost twice that of those expected in CSTP, but the stages at which the differences were observed differed. $N G F 2$ expressed at double ridge stage to floret differentiation stage and $H D B 2$ and $H C G 4$ expressed at pistil and stamen-differentiating stage.
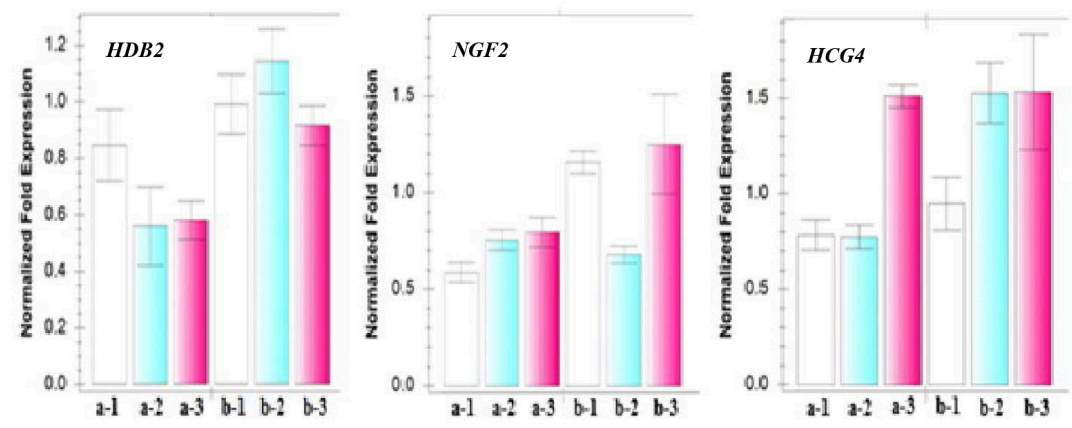

Figure 4. Validation of overexpression of DEGs by real-time RT-PCR. a: CSTP; b: HTS-1; 1: double ridge stage to floret differentiation stage; 2 : pistil and stamen-differentiating stage; 3 : anther lobe formation stage. 


\section{Sequence data analysis}

The three differential genes were sequenced and subjected to a Blast algorithm search against the protein database at NCBI (http://blast.ncbi.nlm.nih.gov/Blast. cgi\#alnHdr_357156183). The analysis results indicate that HDB2 is a nucleotide that is highly homologous to Brachypodium distachyon DEAD-box ATP-dependent RNA helicase 50-like (Accession No. XM 003577321.1). NGF2 is homologous to the Chinese Spring wheat cDNA (AK335439.1), and the HCG4 gene was not identical to any gene (Table 2).

Table 2. Summary of DEG clones for various lengths of spikelets of the pistillody wheat and their significant homology matches.

\begin{tabular}{|c|c|c|c|c|c|}
\hline Predicted clones & Sequence length (bp) & Predicted (species) & Predicted (function) & Accession No. & Identities (\%) \\
\hline$H D B 2$ & 924 & Brachypodium distachyon & $\begin{array}{l}\text { DEAD-box ATP-dependent } \\
\text { RNA helicase }\end{array}$ & XM003577321.1 & 90 \\
\hline $\begin{array}{l}N G F 2 \\
H C G 4\end{array}$ & $\begin{array}{l}317 \\
545\end{array}$ & $\begin{array}{l}\text { Chinese Spring cDNA, clone } \\
\text { No significant similarity found }\end{array}$ & Predicted protein & AK335439.1 & 100 \\
\hline
\end{tabular}

The functions of the $H D B 2, N G F 2$, and $H C G 4$ genes were predicted using Blastx searches of the sequences against GenBank. The results showed that HDB2 has $99 \%$ homology with the DEAD-box ATP-dependent RNA helicase 50 of Triticum urartu (Accession No. EMS47157.1) and Aegilops tauschii (Accession No. EMT24473.1). NGF2 is 40\% homologous to the predicted protein of Daphnia pulex (Accession No. EFX68030.1; Table 2). However, $H C G 4$ exhibited no similarity to any of the proteins reported, suggesting it is a new gene.

Sequence analysis showed that the HDB2 full-length cDNA is 924 bp in length and has a complete ORF of $570 \mathrm{bp}$, which encodes 189 amino acids. The encoded protein of the HDB2 gene was significantly homogenous to the DEAD-box ATP-dependent RNA helicase of Triticum urartu (EMS47157.1), Aegilops tauschii (EMT24473.1), Brachypodium distachyon (XP_003577369.1), and Zea mays (NP_001146459.1). However, variability was not found in any of the amino acids (Figure 5).

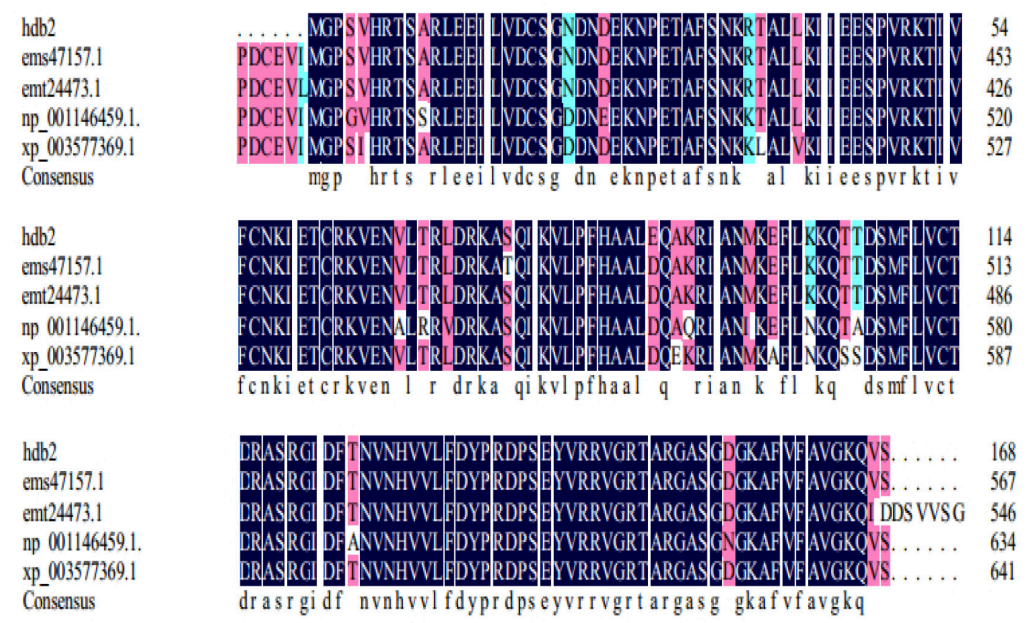

Figure 5. Amino acid comparison of HDB2 and its homologues. 


\section{DISCUSSION}

The pistillody mutant was initially chosen for study because the wheat flower is extremely stable (Schmidt and Ambrose, 1998); moreover, there are limited reports on pistillody wheat. Pistillody phenomena are usually marked by partial or complete sex reversal and are associated with changes in their functions (Murai et al., 2002; 2003). To study the mechanism for the homeotic transformation of stamens into pistils or pistil-like structures in wheat and identify the genes specifically or predominantly expressed in the pistillody wheat, we employed a new differential display RT-PCR technique, the ACP system (Hwang et al., 2003; Kim et al., 2004). Expression patterns were compared between the pistillody mutant HTS-1 and its sib-line CSTP. The basis of the ACP technology is the unique tripartite structure of a specific oligonucleotide primer (ACP), which has distinct 3 ' and $5^{\prime}$ end portions that are separated by a regulator. Each portion of this primer interacts during a two-stage PCR. The structure of ACP comprises a 3' end region with a target core nucleotide sequence that substantially complements the template nucleic acid for hybridization, a $5^{\prime}$ end region with a non-target universal nucleotide sequence, and a poly (dI) linker bridging the $3^{\prime}$ and $5^{\prime}$ end sequences (Hwang et al., 2003; Kim et al., 2004). These 5' end non-target and poly (dI) linker sequences do not interrupt nonspecific hybridization. Therefore, this method has a high reproducibility rate and eliminates false-positive results. The ACP system has been widely used for studies of cell differentiation during animal and plant development (Park et al., 2006; Yang et al., 2011). In the present study, ACP was used to identify potential genes related to the pistillody trait. The results show that all three genes are upregulated in HTS-1, namely, HDB2, NGF2, and HCG4.

After further confirmation using real-time RT-PCR analysis, the three genes were found to be significantly differentially expressed in HTS-1 and CSTP. NGF2 was identified in the double ridge to floret differentiation stages; HDB2 and HCG4 were identified in pistil during the stamen-differentiation stage. Thus, we inferred that the homeotic transformation of stamens into pistil-like structures occurred during the early stage of stamen development.

Peng et al. (2013) proved that some minor genes modified the expression of pistillody, thus enabling the development of complete expressive pistillody wheat (male sterile) lines by gene pyramiding. In this paper, $H D B 2, H G F 2$, and $H C G 4$ amplified in HTS-1 may be minor genes. The incorporation of minor genes and their interaction with other genes in young spike ontogenesis would contribute to the elucidation of their functional areas as meristem identity genes. This implies that the presence or absence of HTS-1 DEGs allowed the specific development of pistils or stamens.

$H D B 2$ was found to have high similarity to the Brachypodium distachyon DEAD-box ATP-dependent RNA helicase on performing Blastx searches of the sequence against GenBank. DEAD-box RNA helicase is a big ATP-dependent RNA helicase family (Rocak and Linder, 2004), and it plays a key role in the metabolic activity of many RNAs (De la Cruz et al., 1999). The current study has shown that DEAD-box RNA helicases are related to flower development in corn (Sommer et al., 1990; Shore et al., 1995) and the formation of the Arabidopsis floral meristem (Jacobsen et al., 1999). Furthermore, according to a study on tobacco in 2000, a DEAD-box RNA helicase is coded by the $V D L$ gene and it participates in chloroplast differentiation and plant morphogenesis (Wang et al., 2000). Based on the above research, we inferred that the protein was coded by HDB2 and is involved in the regulation of the HTS-1 pistillody trait.

More research is essential to further analyze pistillody molecular expression. NGF2 
was strongly expressed in HTS-1 and it was homologous to the Chinese Spring cDNA clone by BLAST algorithm search against the NCBI protein database. Further research on its overexpression is required to identify how it is related to the pistillody trait. The function of the proteins homologous to $N G F 2$ could not be identified Thus, we assume that $N G F 2$ is a new functional gene related to the pistillody trait.

Overall, this research is essential to identifying the mechanism of molecular expression and the ontogenetic model of pistillody wheat. It also has implications for understanding the rules of male sterility in wheat and for studying heterosis and variety improvement.

\section{ACKNOWLEDGMENTS}

Research financially supported by the Young Teachers Scientific Research Foundation of China West Normal University (Grant \#13D002), National Natural Science Foundation of China (Grant \#31301319), and key project of the Chinese Ministry of Education (Grant \#211164). The authors would like to thank Dr. J. Yang (China West Normal University, Nanchong) for his thorough revision of the manuscript.

\section{REFERENCES}

De la Cruz, Kressler D and Linder P (1999). Unwinding RNA in Saccharomyces cerevisiae: DEAD-box protein and related families. Trends Biochem. Sci. 24: 192-198.

Hama E, Takumi S, Ogihara Y and Murai K (2004). Pistillody is caused by alterations to the class-B MADS-box gene expression pattern in alloplasmic wheats. Planta 218: 712-720.

Hanson MR (1991). Plant mitochondrial mutations and male sterility. Annu. Rev. Genet. 25: 461-486.

Hwang IT, Kim YJ, Kim SH, Kwak CI, et al. (2003). Annealing control primer system for improving specificity of PCR amplification. Biotechniques 35: 1180-1184.

Jacobsen SE, Running MP and Meyerowitz EM (1999). Disruption of an RNA helicase/RNAse III gene in Arabidopsis causes unregulated cell division in floral meristems. Development 126: 5231-5243.

Kim YJ, Kwak CI, Gu YY, Hwang IT, et al. (2004). Annealing control primer system for identification of differentially expressed genes on agarose gels. Biotechniques 36: 424-426.

Leighty CE and Sando WJ (1924). Pistillody in wheat flowers. J. Hered. 15: 263-268.

Li Y, Xu PZ, Zhang HY, Peng H, et al. (2007). Characterization and identification of a novel mutant fon(t) on floral organ number and floral organ identity in rice. J. Genet. Genome 34: 730-737.

Livak KJ and Schmittgen TD (2001). Analysis of relative gene expression data using real-time quantitative PCR and the $2^{-\Delta \Delta C t}$ method. Methods 25: 402-408.

Manickavelu A, Kambara K, Mishina K, et al. (2007). An efficient method for purifying high quality RNA from wheat pistils. Colloids Surf. B Biointerfaces 54: 254-258.

Meguro A, Takumi S, Ogihara Y and Murai K (2003). WAG, a wheat AGAMOUS homolog, is associated with development of pistil-like stamens in alloplasmic wheats. Sex Plant Reprod. 15: 221-230.

Mitchell CH and Diggle PK (2005). The evolution of unisexual flowers: morphological and functional convergence results from diverse developmental transitions. Am. J. Bot. 92: 1068-1076.

Mizumoto K, Hatano H, Hirabayashi C, Murai K, et al. (2009). Altered expression of wheat AINTEGUMENTA homolog, WANT-1, in pistil and pistil-like transformed stamen of an alloplasmic line with Aegilops crassa cytoplasm. Dev. Genes Evol. 219: 175-187.

Murai K and Tsunewaki K (1993). Photoperiod-sensitive cytoplasmic male sterility in wheat with Aegilops crassa cytoplasm. Euphytica 67: 41-48.

Murai K, Takumi S, Koga H and Ogihara Y (2002). Pistillody, homeotic transformation of stamens into pistil-like structures, caused by nuclear-cytoplasm interaction in wheat. Plant J. 29: 169-181.

Murai K, Miyamae M, Kato H, Takumi S, et al. (2003). WAP1, a wheat APETALA1 homolog, plays a central role in the phase transition from vegetative to reproductive growth. Plant Cell Physiol. 44: 1255-1265.

Park JS, Kim IS, Cho MS, Park S, et al. (2006). Identification of differentially expressed genes involved in spine formation 
on seeds of Daucus carota L. (carrot), using annealing control primer (ACP) system. J. Plant Biol. 49: 133-140.

Peng ZS (2003). A new mutation in wheat producing three pistils in a floret. J. Agron. Crop Sci. 189: 270-272.

Peng ZS, Yang J, Wei SH and Zeng JH (2004). Characterization of common wheat (Triticum aestivum L.) mutation line producing three pistils in a floret. Hereditas 141: 15-18.

Peng ZS, Martinek P, Kosuge K and Kuboyama T (2008). Genetic mapping of a mutant gene producing three pistils per floret in common wheat. J. Appl. Genet. 49: 135-139.

Peng ZS, Yang ZJ, Ouyang ZM and Yang H (2013). Characterization of a novel pistillody mutant in common wheat. Aust. J. Crop Sci. 7: 159-164.

Rocak S and Linder P (2004). DEAD-box proteins: the driving forces behind RNA metabolism. Nat. Rev. Mol. Cell Biol. 5: 232-241.

Saraike T, Shitsukawa N, Yamamoto Y, Hagita H, et al. (2007). Identification of a protein kinase gene associated with pistillody, homeotic transformation of stamens into pistil-like structures, in alloplasmic wheat. Planta 227: 211-221.

Schmidt RJ and Ambrose BA (1998). The blooming of grass flower development. Curr. Opin. Plant Biol. 1: 60-67.

Shitsukawa N, Kinjo H, Takumi S and Murai K (2009). Heterochronic development of the floret meristem determines grain number per spikelet in diploid, tetraploid and hexaploid wheats. Ann. Bot. 104: 243-251.

Shore P and Sharrocks AD (1995). The MADS-box family of transcription factors. Eur. J. Biochem. 229: 1-13.

Sommer H, Beltran JP, Huijser P, Pape H, et al. (1990). Deficiens, a homeotic gene involved in the control of flower morphogenesis in Antirrhinum majus: the protein shows homology to transcription factors. EMBO J. 9: 605-613.

Tiwari VK, Lopez K, Riera-Lizarazu O, Kianian SF, et al. (2011). Physical mapping of compactum and three pistil loci on wheat chromosome 2D using radiation hybrids. Plant and Animal Genomic XIX Conference, January 15-19. San Diego, California USA.

Wang Y, Duby G, Purnelle B, Boutry M (2000). Tobacco VDL gene encodes a plastid DEAD-box RNA helicase and is involved in chloroplast differentiation and plant morphogenesis. Plant Cell 12: 2129-2142.

Wang XJ, Liu W, Chen XM, Tang CL, et al. (2010). Characterization of two thioredoxins $h$ with predominant localization in the nucleus of aleurone and scutellum cells of germinating wheat seeds. Plant Mol. Biol. 46: 361-371.

Yamada K, Saraike T, Shitsukawa N, Hirabayashi C, et al. (2009). Class D and B (sister) MADS-box genes are associated with ectopic ovule formation in the pistil-like stamens of alloplasmic wheat (Triticum aestivum L.). Plant Mol. Biol. 71: 1-14.

Yang ZJ, Peng ZS, Wei SH, Yu Y, et al. (2011). Identification of differentially expressed genes in three-pistil mutation in wheat using annealing control primer system. Gene 485: 81-84.

Zhu Y, Saraike T, Yamamoto Y, Hagita H, et al. (2008). orf260cra, a novel mitochondrial gene, is associated with the homeotic transformation of stamens into pistil-like structures (pistillody) in alloplasmic wheat. Plant Cell Physiol. 49: 1723-1733. 